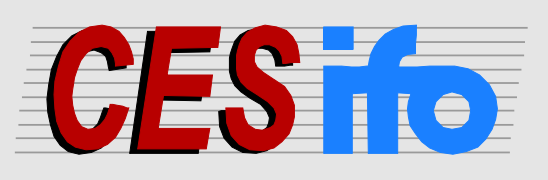

\title{
Working
}

Papers

www.cesifo.org/wp

\section{Retiree Health Insurance for Public School Employees: Does it Affect Retirement?}

\author{
Maria D. Fitzpatrick
}

CESIFO WORKING PAPER NO. 4415

CATEGORY 5: ECONOMICS OF EDUCATION

SEPTEMBER 2013

\footnotetext{
An electronic version of the paper may be downloaded

- from the SSRN website:

- from the RePEc website:

WwW.SSRN.com

www.RePEc.org

- from the CESifo website:

www.CESifo-group.org/wp
}

\section{CESifo}




\title{
Retiree Health Insurance for Public School Employees: Does it Affect Retirement?
}

\begin{abstract}
Despite the widespread provision of retiree health insurance for public sector workers, little attention has been paid to its effects on employee retirement. This is in contrast to the large literature on health-insurance-induced "job-lock" in the private sector. I use the introduction of retiree health insurance for public school employees in combination with administrative data on their retirement to identify the effects of retiree health insurance. As expected, the availability of retiree health insurance for older workers allows employees to retire earlier. These behavioral changes have budgetary implications, likely making the programs selffinancing rather than costly to taxpayers.
\end{abstract}

JEL-Code: J260, H750, I280, I210.

Keywords: retirement, health insurance, public sector employment, teacher labor supply.

\author{
Maria D. Fitzpatrick \\ Department of Policy Analysis and Management \\ Cornell University \\ 103 Martha Van Rensselaer Hall \\ USA - Ithaca, NY 14853 \\ maria.d.fitzpatrick@cornell.edu
}

I would like to thank Michael Lovenheim, Susanna Loeb, Jordan Matsudaira, Melinda Morrill, Joseph Quinn and seminar participants at Cornell University, the NBER Conference on State and Local Health Plans for Active and Retired Public Employees and the CESifo Conference on the Economics of Education for helpful comments and suggestions. Funding from the National Institute on Aging, through Grant Number T32-AG000186 to the National Bureau of Economic Research, is gratefully acknowledged. All errors and omissions are my own. 


\section{Introduction}

In the U.S., as in many other OECD countries, public sector pension funds are severely underfunded. ${ }^{1}$ At the same time, the funds set aside to pay for the health insurance promised to retired state and local government employees, like teachers, represent an even smaller fraction of the estimated future health care liabilities than pension funds do pension liabilities (Clark and Morrill 2010). While the promised pension benefits to public employees are considered constitutionally protected in many states, retiree health insurance is not. Therefore, facing considerable deficits and a poor economic climate, state and local governments may soon decide to discontinue, significantly scale back or otherwise alter retiree health insurance programs for their employees.

Economic theory would predict that the offer of retirement-contingent health insurance to public sector employees would decrease public sector employment of older workers for two reasons. First, there is an income effect of subsidized health insurance that discourages work. Second, health insurance that is tied to retirement from the public employer does not preclude employment in the private sector; the reduction of "job-lock" may lead employees to retire from the public sector but continue to work elsewhere. This option may be particularly attractive to older workers if private sector jobs offer more flexible hours than public employers.

However, there has been relatively little research into the magnitude of any effects of retiree health insurance on public sector employment. Research on similar programs, e.g. Medicare, COBRA and the Veterans Affairs insurance expansion, provides some indication (Gustman and Steinmeir, 1994; Karoly and Rogowski, 1994; Madrian, 1994; Gruber and

\footnotetext{
${ }^{1}$ Novy-Marx and Rauh (2009) estimate U.S. public pension funds are \$3 trillion underfunded. For information on OECD public pensions, see http://www.oecd.org/finance/private-pensions/47827915.pdf.
} 
Madrian, 1995; Lumstaine, Stock and Wise, 1996; Rust and Phelan, 1997; Blau and Gilleskie, 2001, 2006, 2008; Boyle and Lahey, 2010; Robinson and Clark, 2010; Strumpf, 2010; French and Jones, 2011; Coe et al., 2013; Martin and Woodbury, 2013; Nyce et al., 2013). This literature has generally shown that health insurance availablity for retirement-aged individuals induces retirement, though the magnitudes of the effects vary across settings. ${ }^{2}$ Yet, this work has focused on private sector employees. Differences between both public employee retiree health insurance plans and the other types of insurance studied and public and private employees suggest the effects of retiree health insurance may be different across the public and private sectors. For example, research has shown that public sector employees are particularly responsive to the nonlinearities in their pension benefits (Costrell and Podursky 2009; Brown 2010; Koedel et al. 2013; Grissom et al. 2013a; Grissom et al. 2013b) and are more knowledgeable about their retirement benefits (DeArmond and Goldhaber 2010) than their counterparts in the private sector.

More recently, two studies have focused specifically on the effects of retiree health insurance on the labor supply of public sector retirees. Leiserson (2013) uses administrative data on public bureaucrats in Pennsylvania to investigate how employee exit responds to retiree health insurance eligibility. He leverages both the inherent variation caused by standing eligibility requirements for pensions and the retiree health insurance program and a natural experiment caused by an increase in the service requirement for retiree health insurance

\footnotetext{
${ }^{2}$ Evidence from Medicare on labor supply of older Americans is limited, likely in part due to the fact that it is difficult to disentangle the eligibility for Medicare from the eligibility for Social Security and other retirement contingent programs for which people become eligible at age 65. Some existing studies generally overcome this problem using identification assumptions based on functional form and find positive effects (Rust and Phelan, 1997; French and Jones, 2008; Blau and Gilleskie, 2008). An exception is recent work by Coe et al. (2013) who use the decoupling of Medicare and Social Security eligibility that resulted from the increase in the full retirement age for collecting Social Security benefits in a differences-in-differences strategy. They find that Medicare eligibility increases retirement at age 65 by 2.6 percentage points. Similarly, Gruber and Madrian (1995) find that continuation-of-coverage mandates for employees ages 55 to 64 increase retirements.
} 
eligibility (but not pension eligibility) from 15 to 20 years. Shoven and Slavov (2013) use data on all federal, state and local government employees from the Health and Retirement Study coupled with data on pension and retiree health insurance availability and generosity to determine the effects of retiree health insurance on the labor supply of older workers, i.e. those between 58 and 64 . Both studies find that the availability of public employer provided retiree health insurance increases the likelihood that employees will be either out of the labor force or at least no longer working at their public employer.

The current study contributes to this emerging literature because, as described more below, I use administrative data on the single largest group of public sector workers, namely, teachers and other public school employees. ${ }^{3}$ I also leverage a natural experiment different in nature than those used by Leiserson and Shoven and Slavov. Its counterfactual is a world without retiree health insurance in the public sector. Also, similar to the other studies, the nature of my data allow me to pay careful attention to other endogenous factors that may be driving retirement, e.g. pension eligibility and generosity. Moreover, the weakness of my study - my use of data and identifying variation from the early 1980s when labor supply patterns of older workers were likely somewhat different than they are today - does not plague the other studies. As such, the findings of all three studies can be combined to more fully understand the relationship between retiree health insurance and public sector employee labor supply.

To be more specific, in this paper, I provide direct evidence about how public sector retiree health insurance availability affects the labor supply of public employees by examining the introduction of retiree health insurance for public school employees in Illinois. Today, former employees of Illinois Public Schools (IPS) who receive retirement benefits from the ${ }^{3}$ The BLS reports that in May of 2013, there were about 19 million state and local government workers, 53 percent
of which were education related employees. http://www.bls.gov/news.release/empsit.t17.htm 
Illinois Teacher Retirement System (TRS) can participate in a health insurance plan called the Teachers Retirement Insurance Program. The state legislators introduced this retiree health insurance program for teachers and other public school employees, which I call TRHIP, in January of 1980 and permitted the first enrollments on July 1, $1980 .^{4}$ At the time, premiums for enrollees were 50 percent subsidized. In order to enroll, former IPS employees needed to be receiving retirement benefits from the TRS and have at least 8 years of creditable service with the TRS.

Using administrative data from IPS, I use a differences-in-differences framework to compare the labor supply of teachers old enough and with enough accumulated experience to be eligible for TRHIP to those who were ineligible (because they were too young or had too little experience to be eligible for retirement benefits and THRIP) just before and after the TRHIP was introduced. I control for age- and experience fixed effects, thereby capturing any systematic variation in labor supply across the lifecycle and career. The identifying assumption is that, conditional on employee characteristics, there were no other concurrent policies or environmental factors that disproportionately affected the labor supply of teachers eligible for THRIP. Importantly, using historical TRS documents, I can confirm there were no concurrent policy changes by the Illinois TRS related to either pension benefit size or eligibility. To further support the identification assumption, I examine pre-treatment trends in differences in labor supply of the ineligible and eligible public school employees and find no differences.

\footnotetext{
${ }^{4}$ The name Teachers Retirement Insurance Program was introduced in 1995 when the state created the Teachers' Health Insurance Security Fund as an agency (separate from the pension fund) responsible for collecting state, district and employee contributions, managing the investment of funds and providing payment for the healthcare received by members. Before that, the retiree health insurance program was managed by the TRS and generically called the retiree health insurance program. For consistency, and to distinguish it from the program available only after 1995, I will refer to the program as the teachers' retiree health insurance program (TRHIP) throughout the paper.
} 
The outcome of interest is the retirement from the IPS system, which is synonymous with leaving one's career job. I find that eligibility for retirement-contingent health insurance induces a clear shift in the age profile of retirement for public school employees. Before retiree health insurance is introduced, the exit rate of employees from IPS is highest at age 65, when eligibility for Medicare begins. After TRHIP is introduced, the exit rate of employees who continue to be employed at age 65 decreases 40 percent, from 0.51 to 0.29 . At the same time, exit rates when employees first become eligible for retirement benefits at age 55 were just 0.054 before the TRHIP was introduced. Afterwards, the exit rate at this age, which now determines not just eligibility for retirement benefits but also retiree health insurance, jumps to 0.098 , an increase of 81 percent. As we would have expected, the employees whose labor supply is sensitive to the availability of retiree health insurance retire earlier. Those who remain employed to older ages despite their eligibility for pension and retiree health insurance are those whose labor supply is less elastic with respect to such programs.

In Section II, I provide an overview of the Illinois teacher pension and retiree health insurance programs as they exist today, and their historical genesis. I describe the data in Section III and the empirical methodology in Section IV. I present results in Section V before concluding with a brief discussion in Section VI. Implications for employees and governments today are discussed, including how these changes in labor supply affect cost calculations.

\section{Illinois Teacher Retiree Health Insurance Program}

Today, former employees of IPS who receive retirement benefits from the Illinois TRS can participate in a health insurance plan officially called the Teachers Retirement Insurance Program. For retired employees enrolled in the managed care plan, the monthly premium is 
$\$ 203$ if the retiree is under age 65 and $\$ 80.23$ if the retiree is age 65 or older and enrolled in Medicare as the primary insurer. Premiums are higher in the alternative Teachers' Choice Health Plan. Notably, unlike Medicare, the TRHIP program covers dependents, though premiums for dependents are more expensive than premiums for retired employees. Currently, there is no annual or lifetime limit on the coverage in any plan offered by the Illinois TRHIP, making it more generous than Medicare. In the managed care program, there is no annual deductible, though there are copayments for certain services, e.g. \$20 for a physician’s visit. The out-of-pocket maximum is $\$ 3,000$. The Teachers' Choice Health Plan has a $\$ 500$ deductible, but only a \$1,200 out-of-pocket maximum for in-network services.

As mentioned in the introduction, in order to enroll in the TRHIP, former IPS employees must be receiving retirement benefits from the TRS and have at least 8 years of creditable service with the TRS. Eligibility for retirement benefits from TRS is determined by an employee's age and years of creditable service in IPS. ${ }^{5}$ An employee is eligible to receive a full retirement benefit when she is age 55 with at least 35 years of experience, age 60 with at least 10 years of experience, or age 62 with at least five years of experience. During the period studied, employees who had accumulated up to one-half a year of sick leave could count this as creditable service. Additionally, throughout this period, employees could retire at age 55 with just 20 years of experience and receive an actuarially discounted annuity.

The state legislators introduced the health insurance program for retired teachers in January of 1980. The first enrollments were on July 1, 1980. At the time, premiums for enrollees were 50 percent subsidized such that the annuitant’s monthly premium cost was $\$ 81.70$

\footnotetext{
${ }^{5}$ Creditable service can also be earned in Chicago Public Schools or other state employers that have reciprocal arrangements with IPS. Also, employees can pay a fee to have some service credited for time spent teaching in private schools, time in the military, maternity leave, etc.
} 
for people under age 65 and $\$ 29.21$ for people age 65 and older. ${ }^{6}$ The annual deductible was $\$ 847$ and \$7,056 for people on Medicare and those under age 65, respectively. After this deductible was met, all allowable expenses were covered. Initially, and until 1995, the retiree health insurance program was part of the TRS, so the subsidy was financed by funds in the pension system, which were comprised of state appropriations, employee contributions and investment returns.

In the absence of retiree health insurance, the single largest insurance provider for public school retirees was Medicare. In 1980, Medicare consisted of hospital insurance and medical insurance. ${ }^{7}$ For people ages 65 and older who have worked at least 10 years (40 quarters) in jobs that were subject to Medicare FICA taxes, Medicare hospital insurance is free, and was at the time of TRHIP introduction. The same is true if one's spouse worked at least 10 years in a job covered by Medicare taxes. IPS teachers did not pay Medicare taxes on their earnings until after 1986, and even then Medicare taxes were levied only on teachers newly hired by a district. Therefore, even once employees were 65, unless they were eligible for the free hospital insurance through their spouse's work credit, many IPS employees paid a hospital insurance premium. In 2012, the premium for the hospital insurance was scaled based on the amount of FICA covered work history; the highest premium was $\$ 451$ per month. In addition, all Medicare enrollees pay a premium for the medical insurance coverage. In 2012, the base premium was \$99.90 a month, but the premium increased with a beneficiary’s earnings.

\footnotetext{
${ }^{6}$ Premiums and deductibles from 1980 have been converted to \$2013. If retirees were Medicare eligible, the teacher retiree health insurance program only paid for the balance of covered expenses minus any Medicare coverage, regardless of the person's actual participation in Medicare.

${ }^{7}$ Medicare Advantage was introduced in 1997 and the prescription drug component of Medicare was passed into law in 2003.
} 
Because they are ineligible for Medicare, IPS employees younger than age 65 would have had one of five options for obtaining health insurance. (These same options also exist for those over age 65.) The first would be to remain employed and receive health insurance through an employer. Since all school districts provide employee health insurance and tenure rules protect the most senior teachers from termination of employment, continuing insurance coverage in this manner would have been at the discretion of the employee. A second way for IPS employees to obtain health insurance was through their spouse. Given that during the period studied most of the employees in my sample were female and likely secondary breadwinners, this may have been a viable alternative to continued employment until Medicare eligibility. ${ }^{8}$ Third, it may have been the case that individual school districts allowed former employees to continue participation in the district's employee health insurance plan after leaving employment with the district. Fourth, retiring employees could have purchased their own health insurance, either through COBRA or the private market. Finally, Medicare ineligible retirees could have gone without any health insurance.

Unfortunately, available data do not allow me to say much about the pre-THRIP insurance coverage of IPS workers. ${ }^{9}$ However, some evidence can be gleaned from the preTRHIP retirement behavior of IPS employees. In Panel 1 of Figure 1, I plot retirement rates of IPS employees by age from the period before the TRHIP became available (1971 to 1979, the dashed blue line). There are noticeable increases in retirement behavior that correspond to the eligibility for pension benefits that some employees obtain at age 55 and age 60 . But, by far the

\footnotetext{
${ }^{8}$ In the 1980 Census, 75 percent of the teachers (and former teachers) in Illinois between the ages of 50 and 75 were female. Also, nearly 70 percent of these teachers were married (Ruggles et al. 2010).

${ }^{9}$ At the time of introducing the retiree health insurance program, the TRS conducted a survey of a randomly selected subset of its members to gather information about their insurance coverage that could be used in shaping the policy offered by TRS. Unfortunately, according to correspondence with TRS representatives, the results of this survey cannot be found.
} 
most notable spike in the retirement rate of IPS employees occurs at age 65 and $66 .{ }^{10}$ In fact, the retirement rate at age 65 is at least twice as large as the retirement rate for employees of any other age before age 65. Based on this figure, it is clear that eligibility for Medicare is a strong factor determining retirement behavior before retiree health insurance is introduced.

\section{Data}

The main sources of data are IPS administrative files called the Teacher Service Record (TSR) for 1970-1971 to 1991-1992 school years. ${ }^{11}$ (For the rest of the paper, I will refer to school-years by their spring year.) Each observation in the data contains information about an employee’s service in a particular year including her experience, salary, position (teacher, principal, etc.) and main assignment (math, reading, special education, etc.) at a school. I omit the 3 percent of employees who work at vocational schools, schools in prisons, special education cooperatives, etc. Employees in Chicago Public School participate in a separate pension and retiree health insurance program from employees in other public schools in Illinois. For this reason, and because employee records for Chicago are only available beginning in 1979, I drop employees of Chicago public schools from the analysis. ${ }^{12}$ Therefore, my results may not be representative of employees of public schools in extremely large cities.

\footnotetext{
${ }^{10}$ Age is recorded only in years (rather than exact date of birth). This means some employees appear to retire at an age a year older than they truly do.

${ }^{11}$ The TSR continues collecting data after 1992, which is what allows me to define exit between 1992 and 1993. I use only the data from 1971 to 1992 because a large early retirement incentive for employees of the IPS was introduced in 1993 and led to a large number of retirements.

${ }^{12}$ One may be concerned that differential attrition into Chicago Public Schools (CPS) or movement from CPS to IPS may bias the estimated effects of pension and retiree health insurance eligibility. To get a sense of how problematic this could be, I looked at patterns of movement between CPS and IPS over the period in which I have information on CPS, 1979 to 1992. Although CPS employees make up about 20 percent of the public school employees over this period, at most a few hundred employees move between CPS and IPS in any given year. This represents less than one-tenth of overall movement across districts and less than one-quarter of one percent of all employees. Moreover, the movement between CPS and IPS is concentrated among employees with less than 5 years of service.
} 
An employee is eligible for the retiree health insurance with TRHIP when she leaves employment in IPS and begins collecting retirement benefits. The focus here is the effect this eligibility for retiree health insurance has on employee labor supply, namely on an employees’ decision to stop working in IPS. Therefore, I use termination of employment with IPS as the dependent variable. In other words, the dependent variable is a dichotomous variable equal to one if the employee permanently discontinues employment with IPS after year $t$ and 0 otherwise. I refer to this exit behavior as retirement, though it may not be synonymous with complete exit of the labor force if public school employees become employed elsewhere, e.g. the private sector, after discontinuing employment with IPS.

Other covariates of interest include age, years of experience, educational attainment, position (or title) and main employee assignment. ${ }^{13}$ Because I am interested in the labor supply decisions of older workers with respect to their pension and retiree health insurance eligibility, I further limit the sample to only include workers ages 50 and older who are vested in the pension system (i.e. have at least 6 years of service). ${ }^{14}$ For an employee’s years of experience, I use only the years of service accrued in IPS, which does not include service in public schools that are outside of Illinois or reciprocal service earned in other Illinois public employee retirement systems or private schools. While the former does not count as creditable service in the TRS system, the latter does. Not observing this information means there is measurement error in my controls for pension and TRHIP eligibility. To the extent that accrued experience in IPS does

\footnotetext{
${ }^{13}$ Information on employee age comes from the TRS. The two systems do not have a common identifier, but I used employees' names, years of service and employer information to link the datasets. Sometimes an employee could not be matched to the retirement system's age data. In this case, I impute her age based on her other observed characteristics. Observations with imputed age make up one percent of the sample. The likelihood of missing age information does not vary with treatment and results using other reasonable alternative choices of samples or specifications to account for missing data yield statistically indistinguishable results from those presented here. More information and results available from the author upon request.

14 The restrictions based on age and years of service do not change the results. Results using broader samples are available from the author upon request.
} 
not capture the full credited experience with TRS, I will be underestimating some employees’ creditable experience. ${ }^{15}$ As such, I will be classifying some employees as ineligible who are actually eligible. This will lead me to underestimate the effects of both pension and TRHIP eligibility.

Educational attainment falls into one of four mutually exclusive categories: Bachelors degree, Masters degree, Doctorate, or other (including RN degrees and special certificates). I group employees into nine distinct position categories: superintendent, principal, dean, administrative staff, teacher, special education teacher or specialist, health related staff, other staff, and final category for those employees whose position information is missing in the data. I group teaching assignment categories in the following way: English as a second language, foreign languages, sciences, reading, social sciences, math, teachers in self-contained classrooms, other assignments, and a final category for employees whose assignment is unknown or missing in the data. Finally, I also include a measure of the employee's annual salary in IPS, which I convert to $\$ 2013$.

In Table 1, I present summary statistic information for the 405,139 IPS employee-year observations in the data. Ten percent of these older employees leave IPS each year, on average. The average age over the period from 1971 to 1992 was 56. The mean experience in IPS of the employees in my sample is 22 years and the average salary is $\$ 66,519$. Forty percent of employees hold Bachelor's degrees and 55 percent Master's degrees. The remaining employees are about equally likely to either hold a doctorate or some other degree. The vast majority of the employees in the sample are teachers (74 percent) or special education teachers and specialists (5 percent). Nine percent are superintendents, principals or deans. Another 12 percent of

\footnotetext{
${ }^{15}$ Using data on a subset of TRS members, I found that 28 percent had some additional purchased or reciprocal service. The average amount of additional service among purchasers was 3.6 years.
} 
employees are staff. The assignments of teachers are also detailed in the table. Self-contained teachers comprise approximately one quarter of the sample, and math and reading teachers are another 13 percent. The 25 percent of the sample that has an unknown main assignment classification is largely made up of administrators and staff without instructional duties.

\section{Difference-In-Differences Strategy}

In order to identify the effects of availability of retiree health insurance on the labor supply of older public employees, I make use of the fact that the eligibility for TRHIP was determined by an employee's age and experience. Note that this is true for two reasons. First, in order to collect the retiree health insurance an employee must be collecting a pension benefit from TRS and pension-benefit eligibility is determined only by age and years of service. Second, even among the pension eligible, those with 8 years of service or more are explicitly eligible for retiree health insurance, while those with less than 8 years of experience are not. Therefore, I use a difference-in-differences strategy that compares exit behavior of pension eligible employees with at least 8 years of service before and after they were also eligible for TRHIP to that of observationally equivalent employees who are either pension ineligible or have less than 8 years of service (or both) before and after TRHIP introduction.

The value of TRHIP is determined by the availability of alternative forms of insurance, most notably Medicare, and eligibility for Medicare is determined by age. In the pre-TRHIP period, if an employee did not have access to insurance through her spouse or to retiree insurance through her school district of employment, waiting until age 65 to retire allowed employees to avoid forgoing insurance or paying the high costs of privately insuring themselves. After TRHIP introduction, there was no longer a need to delay retirement until age 65 solely for the sake of 
insurance. Instead, employees were eligible for retiree health insurance any time after they reached age 55 and met the requirements for pension eligibility and TRHIP. Therefore, I examine how the effects of TRHIP introduction on retirement behavior vary by the age of employees.

To determine the effects of TRHIP on public employee retirement, I estimate the following equation, equation (1):

$Y_{i d t}=\alpha+\sum_{a g e} \pi^{a g e}$ Eligible $_{i d t}+\sum_{a g e} \beta^{a g e}$ EligibleXPost $_{i d t}+\gamma X_{i d t}+\delta^{e x p}+\varphi^{a g e}+\theta_{d t}+\varepsilon_{i d t}$.

The outcome measure, $Y_{\text {idt }}$, is a dichotomous variable with a value of one if the teacher i in district $d$ exits IPS after school-year $t$ and zero otherwise. ${ }^{16}$ The vector $\mathrm{X}$ includes measures of teacher and district characteristics that vary over time, including measures of employee’s educational attainment, position in the school (e.g. principal, teacher, staff, etc.), subject matter of specialization, and salary as described in the previous section. There is a full set of districtby-year fixed effects, $\theta_{d t}$, which capture any district-year-specific shocks to employee labor supply across districts, such as those resulting from changing macroeconomic conditions. Standard errors are clustered at the experience-level to account for any serial correlation in the error terms within employees of similar experience. ${ }^{17}$

The variable Eligible $_{i d t}$ is a dummy variable indicating that teacher $i$ employed at district $d$ is eligible for a full retirement benefits and has at least 8 years of service in year $t$. The

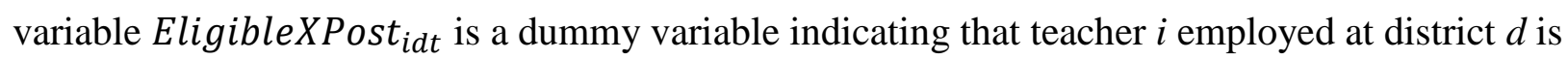
eligible for full retirement benefits has at least 8 years of service in year $t$ and that the observation occurs after TRHIP was introduced, i.e. post-1979. Both of these variables

\footnotetext{
${ }^{16}$ Here, I estimate linear probability models. The conclusions are similar using either probit or hazard models. Results available from the author upon request.

${ }^{17}$ I have also conducted the analyses with standard errors clustered at the level of employees' age or at the district level. The results are similar to those reported and available from the author upon request.
} 
measuring eligibility are interacted with age-category or age-specific fixed effects (depending on the specification) allowing me to obtain coefficient estimates of the effects of full-retirementbenefit eligibility and THRIP eligibility on retirement behavior, $\pi^{a g e}$ and $\beta^{a g e}$, respectively, for employees who remain employed until that age. The model also includes experience fixed effects. Therefore, the effects of pension eligibility on the retirement of employees by age, $\pi^{a g e}$, are identified by the differences in retirement behavior across individuals of the different ages who have the same amounts of accrued service, e.g. the 59 year old with 30 years of experience who is ineligible as compared to the 60 year old with 30 years of experience who is eligible. ${ }^{18}$ (Recall that I have also included age fixed effects, thereby controlling for average differences in retirement propensity throughout the lifecycle.)

The effects of retiree health insurance eligibility, $\beta^{\text {age }}$, are identified off of differences between the retirement behavior of eligible employees before and after July 1980, the point when TRHIP was introduced. One limitation of much of the existing literature is the lack of data or identifying variation that allows for distinction between eligibility for retiree health insurance and eligibility for pension benefits. During the time period I study, the eligibility for and generosity of pension benefits did not change. Comparing the retirement behavior of employees who are pension eligible to the behavior of employees with of the same age and with the same accumulated experience who are both pension and TRHIP eligible allows me to disentangle the effects of pension benefit eligibility from TRHIP eligibility. The underlying assumption in using

\footnotetext{
${ }^{18}$ The underlying assumption in interpreting the $\pi \mathrm{s}$ as estimates of pension-eligibility is that there are no systematic differences in retirement behavior across people of the same age who have accumulated slightly different amounts of experience other than those driven by their eligibility for pension benefits. However, the labelling and interpretation of the $\pi \mathrm{s}$ as the effects of pension eligibility is not completely precise because there are some pensioneligible employees - those over age 62 with 5 to 7 years of service - who are not defined as eligible in equation (1). As such, they remain in the comparison group, which likely renders these coefficient estimates smaller than the true effects of pension eligibility for those ages 62 and older. Similarly, there is an early retirement option to retire with a discounted annuity at age 55 with 20 years of service. Since some employees aged 55 to 59 in the comparison group are eligible for early retirement, the estimates of the effects of pension eligibility are likely biased downward.
} 
this interpretation of the $\beta$ s is that there were no other concurrent policy or environmental changes that would have affected pension-eligible employees with at least 8 years of service differently than other ineligible employees of similar age and experience. In Section V, I show results of event style models with distributed lags and leads that show no evidence of differential trends.

Before turning to the estimates, it is worth noting that the fact that the TRHIP was a newly introduced program means the counterfacutal in this setting is a world with pensions, but no insurance. Therefore, the effects of TRHIP I estimate may not be the same as introducing TRHIP for people who are not pension eligible. These results may, however, speak to the question of what changes in retirement patterns we would see if retiree health insurance eligibility ages are increased without concurrent increases in the age of eligibility for pensions.

\section{$V$. Effects of Retiree Health Insurance Availability on Retirement Behavior}

\section{Graphical Evidence}

Before turning to the difference-in-difference estimates of the effects of TRHIP on employee exit, it is helpful to look at the raw data for evidence of an effect. As described, in Panel A of Figure 1 the dashed line presents information on the retirement rates of public school employees by age before retiree health insurance was provided by the state. There are local peaks at the places where pension eligibility changes discretely, ages 55 and 60, and a rather large global peak in retirement rates at age 65 and 66, when an employee becomes eligible for Medicare.

The solid line in the figure traces retirement rates for public school employees by age in the period after TRHIP is introduced. Notice that, relative to pre-TRHIP levels, the retirement rate increases at the age when employees first become eligible for either retiree health insurance 
or a pension, i.e. age 55, but the rate of retirement at age 65 decreases significantly. This is suggestive that public school employees change their labor supply decisions in response to the availability of retiree health insurance by retiring earlier than they otherwise would have. Employees whose labor supply is elastic with respect to the availability of retiree health insurance retire when it becomes available to them, e.g. at age 55 if they have accrued enough experience. The retirement rates at older ages are no longer as sensitive to the Medicare eligibility because only those employees who have a strong attachment to the labor force (and whose labor supply is therefore less responsive to health insurance availability) remain employed until reaching these older ages.

Because TRHIP was introduced at a point in time, not for a particular cohort, many public school employees may not have been eligible for TRHIP at the same time they became eligible for their pension. This is because many employees may have already passed the age and years-of-service combination required for pension eligibility pre-1980. (For example, consider the 60 year old person in 1979. The introduction of retiree health insurance in 1980 cannot shift her retirement to be at any age earlier than 61.) For these constrained employees, the shifting forward of retirement rates with retiree health insurance eligibility in Figure 1 will be an underestimate of the true shift in retirement rates had they always had access to retiree health insurance.

Therefore, in Figure 1, Panel B, I plot exit rates of three groups of employees by their age in 1980. First is the solid line, indicating the retirement rates of employees by age before the TRHIP is introduced. (This is the same as the dashed blue line in Panel A.) Second, I have split the retirement rates after the program into two groups: those who were ages 54 and younger before TRHIP was introduced (and could therefore more fully adjust their retirement decision to 
its availability) and those who were 55 or older when TRHIP was introduced (and may therefore have been limited in terms of their behavioral adjustment). The line with smaller dashes traces exit rates of the former, and the line with longer dashes traces those for the latter. As would be expected, the retirement of employees who are younger when the program is introduced has more time to adjust and there is a larger response of their labor supply across ages.

Pensions and retiree health insurance might not only make retirement at certain ages more attractive due to their income effects, but the nonlinearities in the eligibility rules mean there are large returns to some employees of remaining employed until they become eligible for pension benefits. Since the introduction of TRHIP made retirement-benefit collection more attractive, in addition to making eligible employees more likely to retire, it may have also made those approaching eligibility less likely to retire. Looking at Figure 1, there is little evidence of this happening. Individuals ages 40 to 54 have very similar exit rates regardless of the availability of retiree health insurance. ${ }^{19}$

\section{Difference-in-Difference Estimates}

As indicated in the descriptive tabulations of exit rates with age before and after TRHIP presented in Figure 1, the difference-in-difference estimates also show that exit of public school employees is responsive to the incentives of both the pension and retiree health insurance systems. This can been seen in Table 2, where I report the difference-in-difference estimates of the effects of pension eligibility and TRHIP eligibility for different age groups. Here, I have separately estimated the effects of eligibility for employees who are 55 to 59, 60 to 64, and 65

\footnotetext{
${ }^{19}$ This finding is confirmed by estimating regressions where the age coefficients are allowed to vary over time. There is no pattern of differences in exit rates for those just under age 55 (and therefore just ineligible for pensions) before and after 1980 .
} 
and older. ${ }^{20}$ Across the four columns in the table, estimates are reported for specifications that include different sets of fixed effects. In the first column, the model includes only year, age and years-of-service fixed effects. In the second and third columns, I add first age-by-year and then years-of-service-by-year fixed effects. Finally, in the fourth column, I include both age-by-year and then years-of-service-by-year fixed effects.

Looking across the columns in the table, a few patterns emerge. First, public school employees' retirement is responsive to the nonlinearities in their pension-benefit-accrual formula. For example, employees ages 60 to 64 who are pension eligible are 8 percentage points more likely to retire than 60 to 64 year olds who are not pension eligible. Given that the exit rate of 60 to 64 year olds who are pension ineligible is 0.20 , this represents a 40 percent increase.

Somewhat surprisingly, the 55 to 59 year olds who are pension eligible are no more or less likely than their pension ineligible counterparts to exit. Given that this group has accumulated a large amount of experience at a young age, they likely have strong labor force attachment. However, this is quite close to zero and is not statistically significant across the specifications, indicating that the effects of pension eligibility are negligible for this group. Perhaps this is due to the fact that so few 55 to 59 year olds have obtained the 35 years of experience necessary to be eligible for a full pension, rendering it hard to identify an effect.

At the same time, pension-eligible employees who are 65 or older, and therefore eligible for Medicare, are 26 percentage points more likely to exit than employees of the same age who

\footnotetext{
${ }^{20}$ The relevant rules governing eligibility could allow for meaningful differences in retirement behavior at the following ages: 55, 60 and 62 (because of the rules determining eligibility for full pension benefits) and 65 (because of eligibility for Medicare). In the data, there is little difference in retirement propensities for people ages 60-61 and those ages 62-64, so I group these ages together. Later, I present age-specific effects.
} 
are pension ineligible. ${ }^{21}$ Since there is no discrete change in pension eligibility at age 65 , the increased likelihood of retirement for those 65 and older can be attributed entirely to their eligibility for Medicare. Clearly, health insurance eligibility was a key factor in the retirement decisions of public school employees even before their employer offered a retiree health insurance program.

Turning to the effects of retiree health insurance eligibility, the effect for 55 to 59 year olds is positive, but not consistent in magnitude or statistical significance across the specifications reported in Table 2. The coefficient estimates of the effect of TRHIP eligibility on the retirement of 60 to 64 year olds is quite close to zero and rarely statistically significant. However, retiree health insurance has a large effect on exit rates of those IPS employees who remain employed at ages 65 and older. For these employees, TRHIP eligibility results in an 18 to 24 percentage point decrease in the propensity to retire.

Recall that employees 65 and older who are pension eligible are 29 percentage points more likely to retire than those who are pension-ineligible. Adding $\pi$ and $\beta$ for those over age 65 shows that employees of these ages eligible for both pensions and retiree health insurance are 5 to 11 percentage point more likely to retire than those ages 65 who are ineligible. However, the combination of eligibility for both pension benefits and health insurance before age 65 renders 65 a less salient age for retirement. Said differently, once TRHIP is introduced, pension-eligible employees are much less likely to wait until after age 65 to retire. ${ }^{22}$ This is likely because the employees whose labor supply is elastic with respect to health insurance availability retire earlier

\footnotetext{
${ }^{21}$ Notably, pension ineligible 65 year olds or those with less than 8 years of service are 8 percentage points more likely than pension ineligible 64 year olds to exit. This is calculated as the difference between the estimates of the age-specific fixed effects for 64 and 65 year olds from the specification in Column 1 of Table 2.

${ }^{22}$ The importance of age 65 for pension ineligible employees remains the same before and after TRHIP introduction, as indicated by little change in the difference between the estimates of age-specific fixed effects for 64 and 65 year olds over time. Results not reported here, but available from the author upon request.
} 
than age 65. Because this pattern does not become clear with age-group eligibility controls, I now turn to estimates of age-specific pension and retiree health insurance eligibility effects.

\section{Age-specific Estimates of the Effects of Retiree Health Insurance}

Thus far, when investigating the effects of pension and TRHIP eligibility, I have focused on three age groups: employees ages 55 to 59, 60 to 64 and 65 or older. It may be the case, however, that within these age ranges there are differential responses to the offer of a pension or retiree health insurance. To determine if this is the case, I estimate equation (1) with year-ofage-specific fixed effects in place of the age-group fixed effects. The results of this estimation are presented in Figure 3. For simplicity, I have plotted only the coefficient estimates of the responsiveness of employee exit to pension eligibility (solid black line) and to the eligibility for TRHIP and a pension (dashed grey line), by age. The asterisks next to each age label on the horizontal axis indicate whether the coefficient estimate for the effect of TRHIP eligibility is statistically different than that of pension eligibility (i.e. the 95 percent confidence intervals of the two lines do not overlap). The results in the figure confirm the descriptive information provided in Figure 1. Most strikingly, there is a large statistically significant difference between the retirement rates of employees over age 65 who are eligible for either pensions and TRHIP or pensions alone. There is also a small, but statistically significant, increase in retirement at ages 55 and 56 because of the TRHIP eligibility.

The increases in exit rates at ages 55 and 56 are much smaller than the decreases in exit rates for employees ages 65 and older. However, the number of employees working at age 55 is substantially larger than the number of employees who remain employed until age 65. In order to understand how retiree health insurance affects the composition of teachers, it is useful to 
consider how it would affect a particular cohort. Predicted conditional density functions (CDFs) of exit by age are presented in Figure $4 .{ }^{23}$ The dashed grey line traces the CDF of exit for a cohort of employees before the retiree health insurance is introduced, while the solid black line represents the CDF for a cohort of employees after TRHIP is introduced. Note that the proportion of a cohort that exits at age 55 is much larger after retiree health insurance is introduced, as indicated by the estimates presented in Figure 2. Furthermore, at every age between 55 and 65, a larger fraction of the cohort is predicted to have left employment at IPS if it was eligible for retiree health insurance. It is only beginning at age 65 that slightly more of the cohort ineligible for retiree health insurance has exited than the cohort eligible for the insurance. From this evidence, we can conclude that employees are shifting their retirement forward in their careers based on their eligibility for health insurance that is not contingent on their employment.

\section{Event Study-Style Estimates of the Effects of Retiree Health Insurance}

The difference-in-difference estimates show that the retirement of public school employees is sensitive to their retiree health insurance eligibility. The underlying assumption with the identification strategy used is that there were no other changes to the pension system or other relevant factors that would have affected the retirement behavior of eligible employees differently than that of ineligible employees. To find support for this assumption, I estimate equation (1) using the measure of pension eligibility interacted with dummy variables for each year relative to TRHIP introduction. These eligibility related distributed leads and lags are then

\footnotetext{
${ }^{23}$ To compute these CDFs I use the coefficient estimates underlying Figure 2 to calculate predicted exit rates at each age for the pension-eligible employees and the pension- and retiree health insurance-eligible employees in the sample.
} 
interacted with age-specific fixed effects to determine if there is any time-pattern to the retirement of pension-eligible employees of each age that predates the introduction of TRHIP.

The results of this event-study-style analysis are presented in Figure 4. For the sake of brevity, I present only the estimates for employees ages 55, 65 and 75 in Panels A, B and C, respectively. In each figure, the coefficient estimates are delineated with a solid line and the 95 percent confidence intervals are indicated with the dashed lines. Though the estimates of the coefficients on the year-specific effects and the eligibility variable are noisy, the estimates in Figure 4 suggest that there were no pretreatment trends in retirement rates for these employees. The evidence therefore supports the underlying assumption in my use of a differences-indifferences framework to estimate the effects of retiree health insurance availability on employee exit.

\section{Mandatory Retirement}

Although the estimates presented in Figure 4 show no evidence of pre-existing trends or discrete changes in retirement behavior at any point before retiree health insurance was introduced, over this period there were significant changes to federal laws regarding mandatory retirement. Specifically, in 1978, Congress increased the minimum age for mandatory retirement from 65 to 70 and, in 1986, mandatory retirement was abolished in most industries. Unfortunately, to my knowledge, no data exists on any mandatory retirement policies that applied to the employees in my sample. However, if mandatory retirement age policies had been constraining behavior of IPS workers by forcing them to retire before they would have chosen to leave the public school system, we would expect to see the age at retirement increase, rather than 
decrease as it does here after 1980 . As such, the rolling back of mandatory retirement may lead the estimates presented to be downward biased. ${ }^{24}$

\section{Effects for Different Types of Employees}

The elasticity of labor force participation with respect to subsidized retiree health insurance may differ across different types of employees. The retirement of people with particularly strong labor force attachment, e.g. those more educated and those who have spent effort training to become school leaders or management, is likely to be less elastic than their counterparts who have stronger preferences for leisure. On the other hand, the highest quality school employees might have the best options for employment outside of the public school system, in which case they would be more likely to respond given the outcome as its measured here, exit from the public school system. To investigate whether labor supply responses differ across employees systematically, in Table 3, I present results for different types of employees. Specifically, I estimate the effects of pension and retiree health insurance eligibility by age for groups of employees based on either their position at the school or their highest degree held.

In the first panel, I divide employees into three separate groups based on their position at the school in year $t$ : teachers (and those in special education related positions), staff and leaders. The staff category includes both administrative and health related staff employees, and the leaders include superintendents, principals, and deans. There is no difference in the responsiveness of the retirement of teachers and staff to either their pension eligibility or their eligibility for retiree health insurance. In contrast, the retirement of school leadership is much

\footnotetext{
${ }^{24}$ To determine whether this is the case, I estimate models separately including only years from 1971 to 1985,1979 to 1992 and 1979 to 1985 . The results are statistically indistinguishable from those presented here, but the limited number of years renders the standard errors quite a bit larger than those presented for the entire period.
} 
less elastic with respect to both pension eligibility and TRHIP eligibility at ages 65 and older than that of the teachers and staff at those ages. This suggests that the set of school leaders who remain employed at older ages has stronger labor force attachment than the set of teachers and staff who remain employed at those ages. This is as expected given the extra training and work required to become a school principal, dean or superintendent.

In the second panel in Table 3, I divide employees based on their highest degree completed: Bachelor's, Master’s, Doctorate or any other degree. The retirement of Bachelor's and Master's degree holders is extremely similar to the pattern seen for the whole sample: retiree health insurance availability led employee to be less likely to continue working until they were Medicare eligible, instead deciding to retire at earlier ages. ${ }^{25}$ Similarly, in the third and fourth columns of the second panel, we can see that though the responsiveness of employees with doctorates or other degrees to pension eligibility is the same as those with Bachelor's and Master's Degrees. However, the older workers (those age 65 and older) with doctorates or other degrees are less responsive to the availability of retiree health insurance. This corroborates the evidence for school leaders, but because there are very few employees with PhDs or other degrees, the results are not statistically significant.

\section{Conclusion}

The evidence presented here shows that the retirement behavior of public school employees in Illinois was responsive to the introduction of a retiree health insurance program. The retiree health insurance program served to move forward the timing of job separations for older workers. Although still a salient age for retirement, after retiree health insurance becomes

\footnotetext{
${ }^{25}$ Results using a specification with the eligibility indicators interacted with age-specific fixed effects for teachers with Bachelor's and Master’s Degrees tell a similar story to those in Figures 2 and 3.
} 
available, many fewer employees wait until age 65 to retire. Instead, retiree health insurance leads more employees retire earlier.

The numbers in Figures 3 and 4 imply that roughly 200 more people from each cohort retire either at age 55 or 56, while 200 fewer people wait until after age 65 to retire. The median older worker in IPS retires 2 years earlier than they otherwise would have because of the availability of retiree health insurance. This statistic does not tell us, however, whether this shift corresponds to a small share of workers who would have retired at 65 now retiring at much earlier ages or a larger share of workers retiring just a bit earlier. Bounding exercises such as those suggested by Djebbari and Smith (2008) suggest the latter is more likely, but I cannot rule out the former. ${ }^{26}$

These estimates can be used to calculate a measure of the elasticity of labor force participation with respect to income for older workers in IPS. (This requires assuming that these employees are not moving to other bridge jobs when they exit IPS.) The annual premiums paid by employees younger than 65 were $\$ 2,400$. This represents 12 percent of the annual salary of 55 year olds in 1979. In Figure 4, we see the labor force participation of 55 year olds in about 9 percentage points lower when retiree health insurance is available, which is about a 10 percent decrease in the labor force participation of these 55 year olds. Therefore, a 10 percent increase in annual income would decrease participation of 55 year olds by 8 percent, which implies a

\footnotetext{
${ }^{26}$ Djebbari and Smith (2008) point out that average treatment effects do not translate into information about the entire distribution of treatment effects without additional assumptions about the joint distribution of outcomes for treated and untreated employees. One such assumption is that individuals would retire at least as early with retiree health insurance availability as they would without it. Under this assumption, the effect of retiree health insurance eligibility causes 90 percent of employees to retire between 1 and 3.5 years early. Under an alternatively extreme assumption - that the employees who retire earliest without retiree health insurance availability are those who retire latest once it is introduced - 70 percent of employees retire earlier when retiree health insurance is introduced. Some retire as much as 14 years earlier, but 60 percent of the retirements are between zero and ten years earlier. Because theory predicts the income effect will cause people to retire earlier, which is in line with the first assumption, I prefer the former assumption, but the results of this bounding exercise leave both possibilities open.
} 
labor force participation income elasticity of -0.8 . This is in line with other estimates of the labor force participation of older workers (e.g. Bound 1989) and the response is comparable to that of other similarly aged private and public sector workers to retiree health insurance (Karoly and Rogowski 1994; Blau and Gilleskie 2001; Leisserson 2013).

The sensitivity of the retirement behavior of older teachers to the provision of retiree health insurance shown here has many implications for government budgets. The most direct cost of retiree health insurance in Illinois, the employer's share of the current annual premium, is $\$ 5,208$ per retiree aged 55 to 64 (and less for older workers). This assumes the state continues its 50 percent subsidy of the premium. Although policymakers are most concerned with the current costs of retiree health insurance premiums, it is useful to think carefully about the implications of retiree health insurance over a longer time horizon and on other components of the budget.

A true calculation of the lifetime costs of the policy would take into the full budgetary implications of the results shown here: workers with retiree health insurance are retiring earlier. This has implications for the calculation of annual and lifetime pension benefits, districts' wage bills and the lifetime cost of the retiree health insurance program. For example, employees who retire earlier receive lower pension benefits but for a longer period of time than those who retire later. In this setting, the median retiree leaves at age 57 with 25 years of service rather than 59 with 27 years of service. Because this median retiree is an early retiree and faces an actuarial penalty for retiring early, the present discounted value of her pension is $\$ 76,731$ lower than if she had not had retiree health insurance. ${ }^{27}$ This represents a net savings to the pension system.

Additionally, the true cost to government (or taxpayer) of the retiree health insurance includes its effects on the wage bill of public school employees. This includes a savings in the

${ }^{27}$ I assume a real interest rate of 5 percent and assume the employee dies at age 80. I use the rules of the pension system and average salaries for those with 25 and 27 years of service to calculate the value of the pensions. 
first two years (because $1^{\text {st }}$ and $2^{\text {nd }}$ year teachers have lower salaries than $26^{\text {th }}$ and $27^{\text {th }}$ year teachers) and extra expense in the $3^{\text {rd }}$ through $25^{\text {th }}$ year (since by the third year, the school district is employing a $3^{\text {rd }}$ year teacher rather than a $1^{\text {st }}$ year teacher, and so on). The present discounted value of this change in the wage bill is a net savings of $\$ 10,108$ per teacher. Finally, because the median employee retires at 57 , the lifetime present discounted value of the employer’s direct cost of the subsidized retiree health insurance for her is $\$ 70,248{ }^{28}$

Combining these three component gives a total net lifetime savings of retiree health insurance $\$ 16,591$ per worker. Based on this extremely simplified calculation, if governments revoked their retiree health insurance, rather than saving themselves (and taxpayers) the lifetime costs of the retiree health insurance, $\$ 77,000$, they would actually pay about $\$ 17,000$ more per public school employee. Of course, there are components of costs that I have not included in this calculation (e.g. I did not account for the growth in health care costs, factor in the costs of employee health insurance or include the employee contribution paid to the pension system while she is employed), but the implication remains: understanding the behavioral implications of retiree health insurance alters the cost-benefit calculus of such programs.

Because most retiree health insurance programs in the public sector are not constitutionally protected in the same way pensions are, the programs may become less generous, be dissolved, or be replaced by other forms of insurance. If this happens, the resulting retirements of older public school employees will have productivity effects that will depend on the quality of older versus younger employees. ${ }^{29}$ The effects of changes in retiree health

\footnotetext{
${ }^{28}$ This assumes the government pays 50 percent of the 2012 premium for 18 to 64 year olds, which was $\$ 10,416$, in each year the employee is retired. If premiums for earlier years of the program or the appropriate premiums for those aged above 65 are used, this estimate would be smaller. On the other hand, if health care costs continue to grow, it may be larger.

${ }^{29}$ The question of the relative quality of senior- versus early-career teachers is an open question in the literature (Wiswall, 2011; Rivkin, Hanushek and Kain, 2005; Rockoff, 2004).
} 
insurance will depend on the counterfactual environment, which, due to changes embedded in the Affordable Care Act, is likely to be different in the future than it is now or was in the early 1980s. Regardless, there are likely to be some labor supply effects of changing public sector employee access to retiree health insurance that will in turn have effects on public sector budgets and liability funding. ${ }^{30}$

\footnotetext{
${ }^{30}$ Specifically, even without employer provided retiree health insurance, many public sector retirees will be able to purchase health insurance at full-price in the health care exchange markets. Since these markets will be priced based on the participation of both young, relatively inexpensive to insure and older, more costly to insure people, the market prices for insurance will be lower than if purchased on the current private market. However, even before retiree health insurance was introduced, many public school teachers had the option to purchase insurance through their former employer, pricing in which is akin to the pricing in the mixed market exchanges.
} 


\section{References}

Blau, David M. and Donna B. Gilleskie. 2008. "The Role of Retiree Health Insurance in the Employment Behavior of Older Men.” International Economic Review, 49(2), 475-514.

Blau, David M. and Donna B. Gilleskie. 2006. "Health Insurance and Retirement of Married Couples.” Journal of Applied Econometrics, 21(7), 935-953.

Blau, David M. and Donna B. Gilleskie. 2001. "Retiree Health Insurance and the Labor Force Behavior of Older Men in the 1990s.” Review of Economics and Statistics, 83(1), 64-80.

Boyle, Melissa A. \& Lahey, Joanna N., 2010. "Health insurance and the labor supply decisions of older workers: Evidence from a U.S. Department of Veterans Affairs expansion," Journal of Public Economics, vol. 94(7-8), pages 467-478, August.

Brown, Kristine M. 2010. "The Link Between Pensions and Retirement Timing: Lessons From California Teachers." Manuscript. University of Illinois.

Clark, Robert L. and Melinda Sandler Morrill. 2010. Retiree Health Plans in the Public Sector: Is there a Funding Crisis? Northampton, MA: Edward Elgar Publishing Inc.

Coe, Norma B., Mashfiqur R. Kahn, and Matthew S. Rutledge. 2013. "Sticky Ages: Why Is Age 65 Still A Retirement Peak?” Working Paper 2013-2. Chestnut Hill, MA: Center for Retirement Research at Boston College.

Costrell, Robert M. and Michael Podgursky. 2009. "Peaks, Cliffs, and Valleys: The Peculiar Incentives in Teacher Retirement Systems and Their Consequences for School Staffing." Education Finance and Policy. vol 4(2): 175-211.

DeArmond, Michael and Dan Goldhaber. 2010. "Scrambling the Nest Egg How Well Do Teachers Understand Their Pensions, and What Do They Think About Alternative Pension Structures?" Education Finance and Policy 5(4): 558-586.

Djebbari, Habiba \& Smith, Jeffrey, 2008. "Heterogeneous impacts in PROGRESA," Journal of Econometrics, Elsevier, vol. 145(1-2), pages 64-80, July.

French, Eric and John Bailey Jones. 2011. The Effects of Health Insurance and Self Insurance on Retirement Behavior. Econometrica, 79(3), 693-732.

Grissom, Jason, Cory Koedel, Michael Podursky and Shawn Ni. 2013a. "Defined Benefit Pension Plans and Job Lock: Evidence from the Education Sector.” University of Missouri Working Paper 13-10.

Grissom, Jason, Cory Koedel, Michael Podursky and Shawn Ni. 2013a. "Pension Induced Rigidities in the Labor Market for School Leaders.” University of Missouri Working Paper 1115.

Gruber, Jonathan and Bridgette C. Madrian. 1995. Health Insurance Availability and the Retirement Decision. The American Economic Review, 85(4), 938-948.

Gustman, Alan L. and Thomas L. Steinmeier. 1994. Employer Provided Health Insurance and Retirement Behavior. Industrial and Labor Relations Review, 48(1), 124-140.

Karoly, Lynn A. and Jeannette Rogowski. 1994. "The Effect of Access to Post- Retirement Health Insurance on the Decision to Retire Early." Industrial and Labor Relations Review, 48(1), 103-123.

Koedel, Cory, Michael Podgursky and Shishan Shi (2013). Teacher Pension Systems, the Composition of the Teaching Workforce, and Teacher Quality. Journal of Policy Analysis and Management 32(3): 574-596.

Leiserson, Greg. 2013. "Retiree Health Insurance and Job Separations: Evidence from Pennsylvania State Employees.” Manuscript. Massachusetts Institute of Technology.

Lumsdaine, Robin L., James H. Stock, and David A. Wise. 1996. "Retirement Incentives: The 
Interaction between Employer-Provided Pensions, Social Security, and Retiree Health Insurance.” In Michael D. Hurd and Naohiro Yashiro (Eds.), The Economic Effects of Aging in the United States and Japan (pp. 261-293). Chicago: University of Chicago Press.

Madrian, Bridgette C. 1994. “The Effect of Health Insurance on Retirement.” Brookings Papers on Economic Activity, 25(1), 181-232.

Marton, James and Stephen A. Woodbury. 2013. "Retiree Health Benefits as Deferred Compensation: Evidence from the Health and Retirement Study.” Public Finance Review, 41(1), 64-91.

Novy-Marx, Robert and Joshua D. Rauh. 2009. "The Liabilities and Risks of State-Sponsored Pension Plans" Journal of Economic Perspectives, 23(4): 191-210.

Nyce, Steven, Sylvester Schieber, John B. Shoven, Sita Slavov, and David A. Wise. 2013. "Does Retiree Health Insurance Encourage Early Retirement?” Journal of Public Economics, 104, 40-51.

Robinson, Christina and Robert Clark. 2010. "Retiree Health Insurance and Disengagement from a Career Job.” Journal of Labor Research, 31(3), 247-262.

Rivkin, Steven G., Eric A. Hanushek and John F. Kain. 2005. “Teachers, Schools, and Academic Achievement.” Econometrica 73(2): 417-458.

Rockoff, Jonah E. 2005. "The Impact of Individual Teachers on Student Achievement: Evidence from Panel Data.” American Economic Review Papers and Proceedings 94(2): 247-252.

Steven Ruggles, J. Trent Alexander, Katie Genadek, Ronald Goeken, Matthew B. Schroeder, and Matthew Sobek. Integrated Public Use Microdata Series: Version 5.0 [Machine-readable database]. Minneapolis: University of Minnesota, 2010.

Rust, John and Christopher Phelan, 1997. "How Social Security and Medicare Affect Retirement Behavior in a World of Incomplete Markets,” Econometrica, 65(4): 781-831.

Shoven, John and Sita Nataraj Slavov. 2013. "The Role of Retiree Health Insurance in the Early Retirement of Public Sector Employees.” Prepared for Presentation at the NBER Conference on State and Local Health Plans for Active and Retired Public Employees, August.

Strumpf, Erin. 2010. "Employer-Sponsored Health Insurance for Early Retirees: Impacts on Retirement, Health, and Health Care.” International Journal of Health Care Finance and Economics, 10(2), 105-147.

Wiswall, Matthew. 2011. “The Dynamics of Teacher Quality.” SSRN Working Paper. Available at SSRN: http://dx.doi.org/10.2139/ssrn.1911309. 
Figure 1. Retirement Rates of IPS Employees by Age and Existence of TRHIP

Panel A.

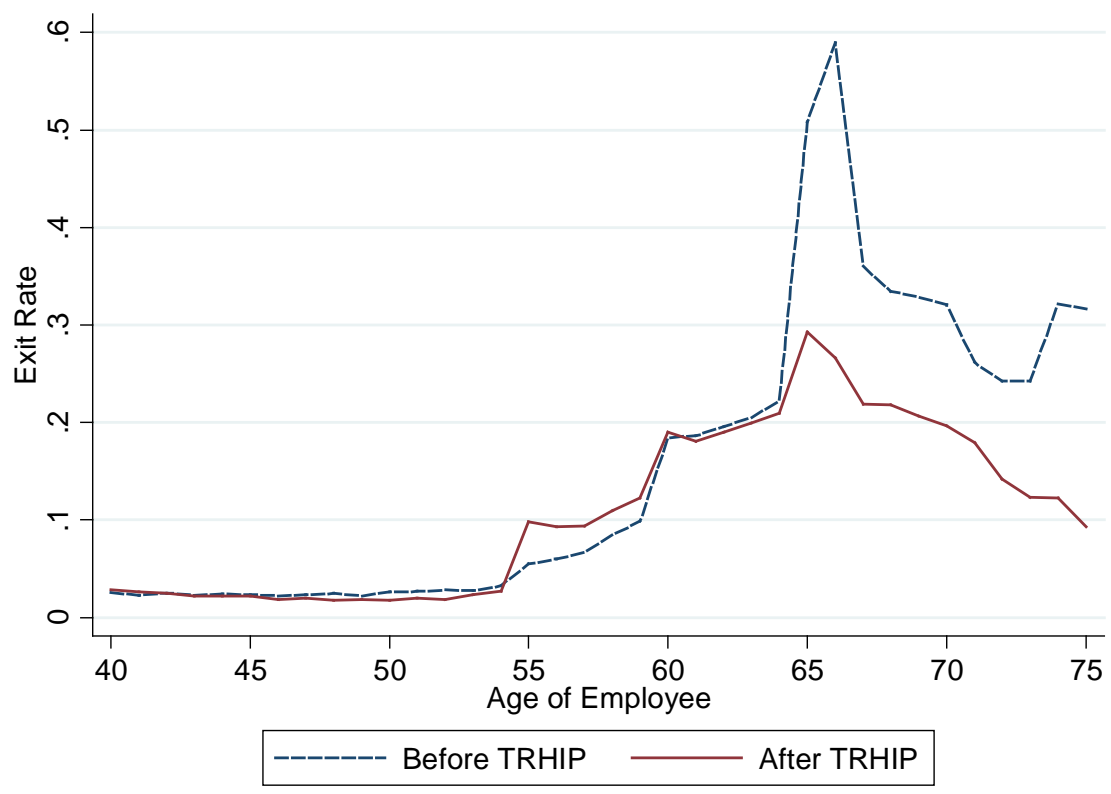

Panel B.

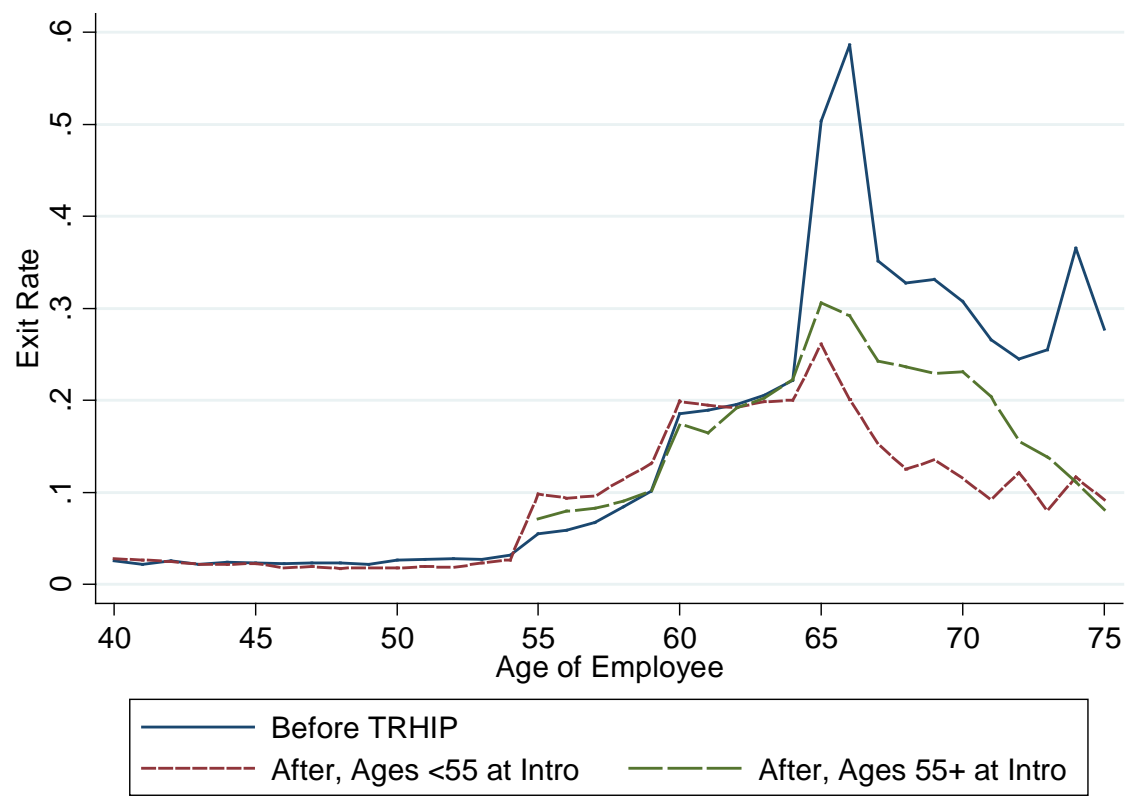

Note: Based on author's calculations using TRS and TSR data on employees of IPS schools from 1971 to 1992 . The 'before TRHIP' period covers 1971 to 1979 and the 'after THRIP' period covers 1980 to 1992 . Only employees ages 40 and older are included in the calculation of exit rates. The exit rate plotted on the vertical axis represents the rate at which employees of each age leave the sample between school year $t$ and $t+1$. 
Figure 2. Estimated Exit Rates of Pension- and Retiree Health Insurance-Eligible Employees Relative to Ineligible Employees, by Age

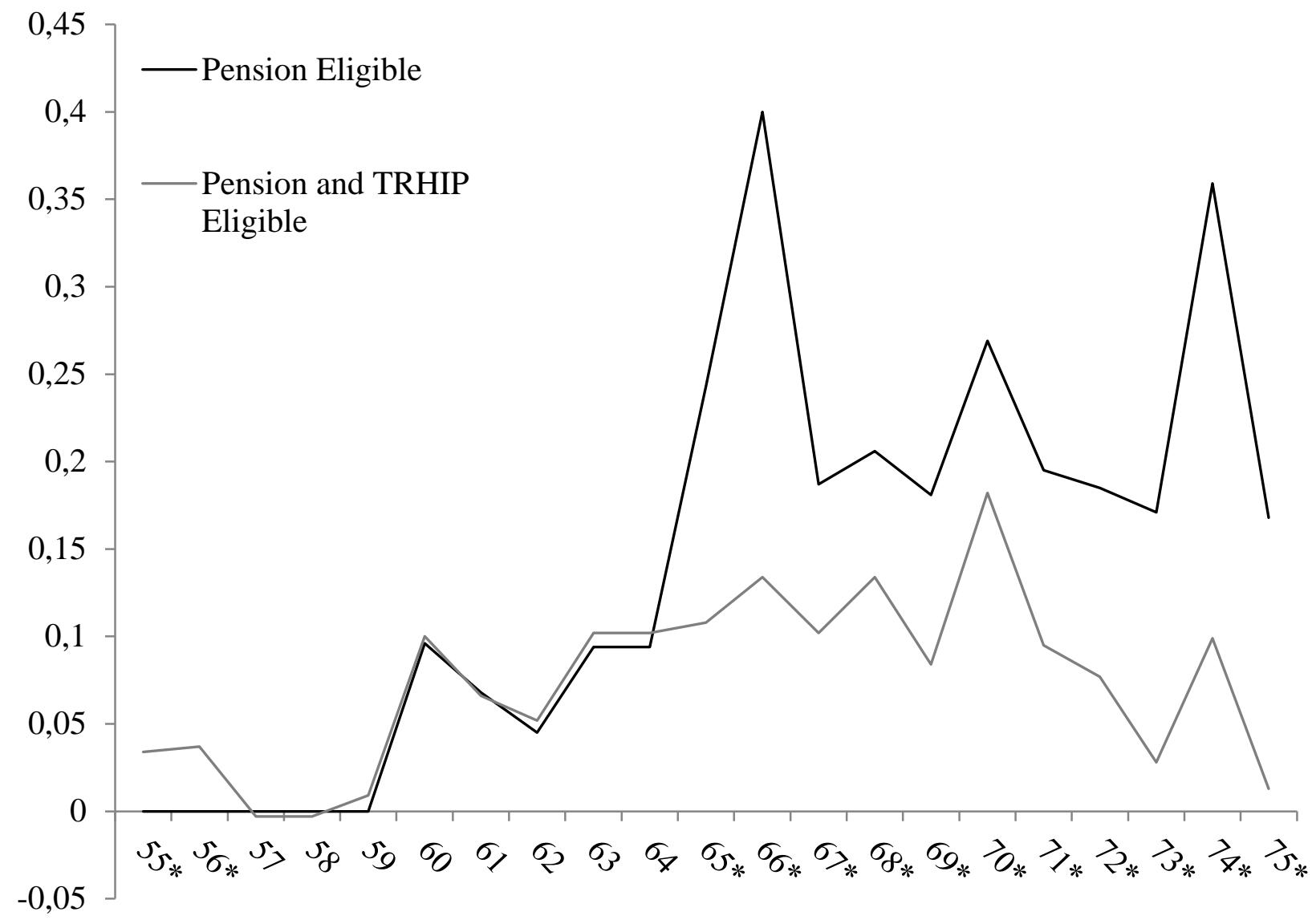

Note: Based on author's calculations using TRS and TSR data on employees of IPS schools from 1971 to 1992. Only employees ages 50 and older who are vested in the pension system are included in the analysis. The exit rate plotted on the vertical axis represents the rate at which employees of each age leave the sample between school year $t$ and $t+1$. The solid black line presents difference-in-difference estimates of the effects of pension eligibility at each age on the horizontal axis from a specification that includes age-by-year, experience-by-year and district fixed effects, as well as other available information on employee characteristics. The dashed grey line presents agespecific difference-in-difference estimates of the effects of pension and retiree health insurance eligibility on retirement rates from the same specification. The plotted exit rates are relative to those of ineligible employees. The asterisks next to each age indicate whether the coefficient estimate for the effect of TRHIP eligibility is statistically different than that of pension eligibility (i.e. the 95 percent confidence intervals of the two lines do not overlap). 
Figure 3. Predicted Conditional Density Function of Exit by Age for a Hypothetical Cohort, by Eligibility for Retiree Health Insurance

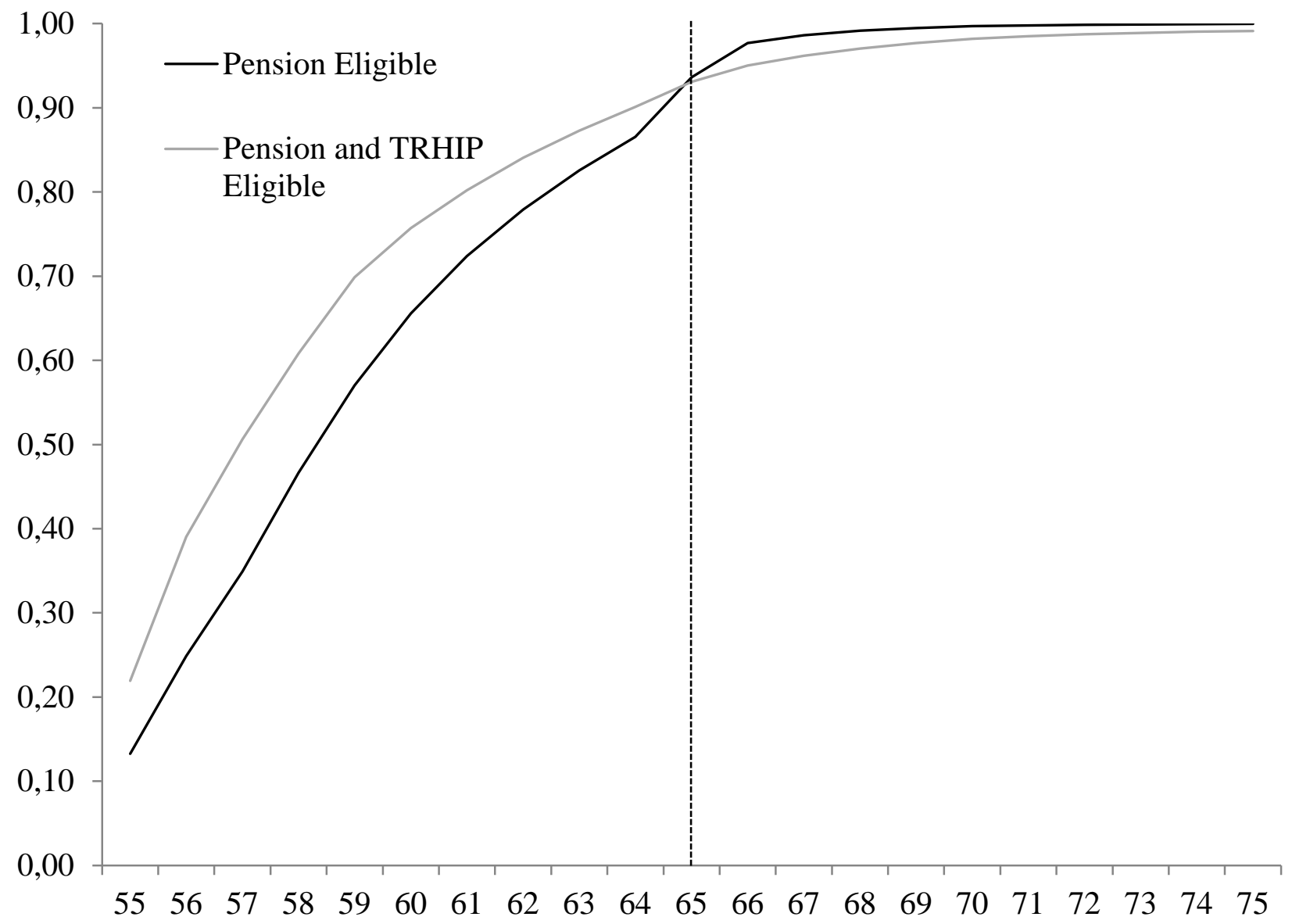

Note: Based on author's calculations using TRS and TSR data on employees of IPS schools from 1971 to 1992.

Only employees ages 50 and older and those vested in the pension system are included in the analysis. The exit rate plotted on the vertical axis represents the rate at which employees of each age leave the sample between school year $t$ and $t+1$. The solid black line presents the predicted CDF for pension-eligible workers at each age indicated on the horizontal axis from a specification that includes age-by-year, experience-by-year and district fixed effects, as well as other available information on employee characteristics. The solid grey line presents predicted CDF for pensionand retiree health insurance-eligible workers from the same specification. 
Figure 4. Event Study Style Estimates of the Effects of Retiree Health Insurance Eligibility on Employee Exit

Panel A. Age 55

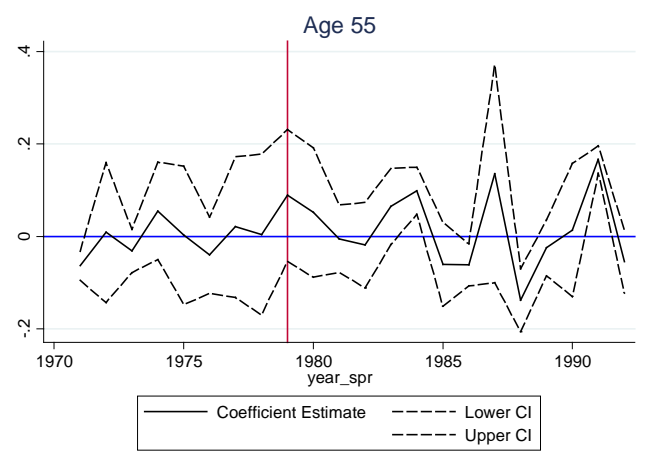

Panel B. Age 65

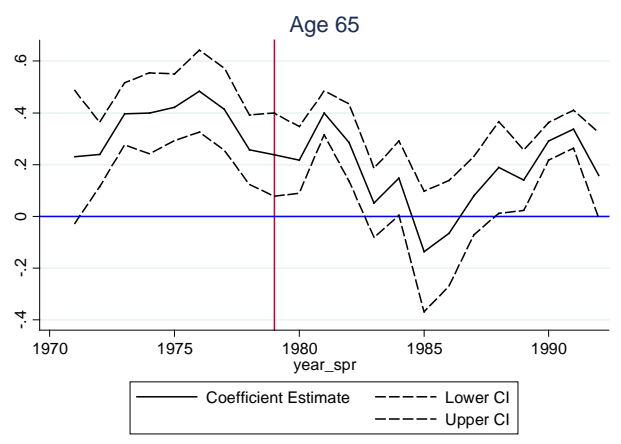

Panel C. Age 75

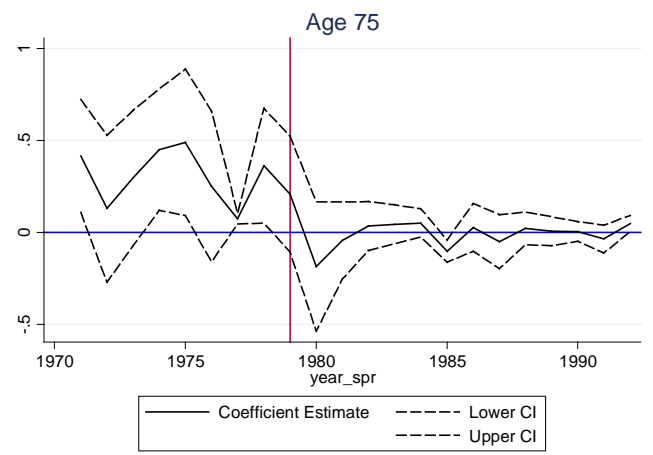

Note: Based on author's calculations using TRS and TSR data on employees of IPS schools or older from 1971 to 1992. The vertical line represents the last period before TRHIP introduction. Only employees ages 50 and older and those vested in the pension system are included in the calculation of exit rates. The exit rate plotted on the vertical axis represents the rate at which employees of each age leave the sample between school year $t$ and $t+1$. Coefficients and confidence intervals plotted are from an event-style model where eligibility for pensions and retiree health insurance are interacted with age-by-year specific dummies. Also included in the specifications are experience-by-year and district fixed effects, as well as controls for employee characteristics. 
Table 1. Descriptive Characteristics of IPS Employees

\begin{tabular}{|c|c|c|}
\hline & Mean & Standard Deviation \\
\hline Exit & 0.096 & 0.295 \\
\hline Age & 56 & 5 \\
\hline Experience & 22 & 8 \\
\hline Salary (thousands \$2013) & 66.519 & 19.991 \\
\hline Other Degree & 0.028 & 0.166 \\
\hline BA Degree & 0.401 & 0.490 \\
\hline MA Degree & 0.552 & 0.497 \\
\hline PhD Degree & 0.019 & 0.137 \\
\hline \multicolumn{3}{|c|}{ Position Held by Employee } \\
\hline Superintendents & 0.034 & 0.182 \\
\hline Principals & 0.056 & 0.230 \\
\hline Deans & 0.004 & 0.062 \\
\hline Administrative Staff & 0.015 & 0.121 \\
\hline Teachers & 0.736 & 0.441 \\
\hline Special Education Position & 0.047 & 0.211 \\
\hline Health Staff & 0.052 & 0.222 \\
\hline Other Staff & 0.056 & 0.230 \\
\hline \multicolumn{3}{|c|}{ Main Assignment of Teachers } \\
\hline ESL & 0.002 & 0.040 \\
\hline Foreign Language & 0.016 & 0.127 \\
\hline Science & 0.041 & 0.199 \\
\hline Reading & 0.090 & 0.286 \\
\hline Social Science & 0.022 & 0.147 \\
\hline Math & 0.036 & 0.187 \\
\hline Self-Contained Classroom & 0.281 & 0.449 \\
\hline Other & 0.258 & 0.438 \\
\hline Unknown & 0.254 & 0.435 \\
\hline
\end{tabular}

Note: Based on author's calculations using TRS and TSR data on employees of IPS schools ages 50 and older who are vested in the pension system from 1971 to 1992. 
Table 2. Difference-in-Difference Estimates of the Effects of Pension and Retiree Health Insurance Eligibility on IPS Employee Retirement, by Age Group

\begin{tabular}{lcccc}
\hline & $(1)$ & $(2)$ & $(3)$ & $(4)$ \\
\hline Pension Eligibility, Ages 55 to 59 & -0.024 & -0.008 & -0.006 & 0.007 \\
Pension Eligibility, Ages 60 to 64 & $(0.016)$ & $(0.016)$ & $(0.016)$ & $(0.017)$ \\
& $0.082^{* * *}$ & $0.076^{* * *}$ & $0.087^{* * *}$ & $0.080^{* * *}$ \\
Pension Eligibility, Ages 65+ & $(0.009)$ & $(0.007)$ & $(0.009)$ & $(0.008)$ \\
& $0.298^{* * *}$ & $0.259^{* * *}$ & $0.302^{* * *}$ & $0.261^{* * *}$ \\
TRHIP Eligibility, Ages 55 to 59 & $(0.020)$ & $(0.022)$ & $(0.021)$ & $(0.022)$ \\
& $0.050^{* * *}$ & $0.027^{* *}$ & $0.022^{*}$ & 0.003 \\
TRHIP Eligibility, Ages 60 to 64 & $(0.011)$ & $(0.012)$ & $(0.012)$ & $(0.012)$ \\
& -0.004 & 0.011 & $-0.011^{* *}$ & 0.005 \\
TRHIP Eligibility, Ages 65+ & $(0.005)$ & $(0.010)$ & $(0.004)$ & $(0.009)$ \\
& $-0.228^{* * *}$ & $-0.177^{* * *}$ & $-0.235^{* * *}$ & $-0.181^{* * *}$ \\
\hline Age FE & $(0.012)$ & $(0.014)$ & $(0.013)$ & $(0.014)$ \\
Experience FE & $\mathrm{Y}$ & $\mathrm{Y}$ & $\mathrm{Y}$ & $\mathrm{Y}$ \\
Year FE & $\mathrm{Y}$ & $\mathrm{Y}$ & $\mathrm{Y}$ & $\mathrm{Y}$ \\
Age x Year FE & $\mathrm{Y}$ & $\mathrm{Y}$ & $\mathrm{Y}$ & $\mathrm{Y}$ \\
Experience by Year FE & & $\mathrm{Y}$ & & $\mathrm{Y}$ \\
\hline Number of Observations & & & $\mathrm{Y}$ & $\mathrm{Y}$ \\
\hline
\end{tabular}

Note: Based on author's calculations using TRS and TSR data on employees of IPS schools from 1971 to 1992.

Only employees ages 50 and older and those vested in the pension system are included in the analysis. Estimates presented are from a differences-in-differences specification in which eligibility for pensions and retiree health insurance are interacted with age-group fixed effects as indicated by the row headers. The specification includes controls for employee characteristics and district fixed effects as well as the other fixed effects indicated. ***, ** and * represent statistical significance at the 1, 5 and 10 percent levels, respectively. 
Table 3. Difference-in-Difference Estimates of the Effects of Pension and Retiree Health Insurance Eligibility on IPS Employee Retirement, by Age Group, Position and Highest Degree Held

\begin{tabular}{lccccccc} 
& \multicolumn{3}{c}{ By Position } & \multicolumn{3}{c}{ By Highest Degree Held } \\
\hline & Teachers & Staff & Leadership & Bachelors & Masters & PhD & Other \\
\hline Pension Eligibility, & 0.007 & -0.007 & 0.011 & 0.008 & -0.002 & 0.010 & $0.050^{*}$ \\
Ages 55 to 59 & $(0.016)$ & $(0.028)$ & $(0.016)$ & $(0.017)$ & $(0.017)$ & $(0.044)$ & $(0.025)$ \\
Pension Eligibility, & $0.081^{* * *}$ & $0.060^{* * *}$ & $0.083^{* * *}$ & $0.082^{* * *}$ & $0.072^{* * *}$ & $0.066^{* *}$ & $0.098^{* * *}$ \\
Ages 60 to 64 & $(0.008)$ & $(0.009)$ & $(0.010)$ & $(0.008)$ & $(0.008)$ & $(0.026)$ & $(0.010)$ \\
Pension Eligibility, & $0.274^{* * *}$ & $0.234^{* * *}$ & $0.169^{* * *}$ & $0.270^{* * *}$ & $0.248^{* * *}$ & 0.092 & $0.273^{* * *}$ \\
Ages 65+ & $(0.024)$ & $(0.026)$ & $(0.022)$ & $(0.025)$ & $(0.022)$ & $(0.061)$ & $(0.024)$ \\
TRHIP Eligibility, & -0.001 & 0.008 & 0.023 & -0.005 & 0.015 & -0.036 & -0.044 \\
Ages 55 to 59 & $(0.011)$ & $(0.022)$ & $(0.021)$ & $(0.012)$ & $(0.013)$ & $(0.050)$ & $(0.039)$ \\
TRHIP Eligibility, & 0.004 & 0.014 & 0.016 & 0.008 & 0.009 & -0.003 & 0.007 \\
Ages 60 to 64 & $(0.009)$ & $(0.012)$ & $(0.012)$ & $(0.010)$ & $(0.010)$ & $(0.032)$ & $(0.020)$ \\
TRHIP Eligibility, & $-0.194^{* * *}$ & $-0.143^{* * *}$ & $-0.110^{* * *}$ & $-0.184^{* * *}$ & $-0.177^{* * *}$ & -0.015 & $-0.105^{* * *}$ \\
Ages 65+ & $(0.014)$ & $(0.023)$ & $(0.019)$ & $(0.015)$ & $(0.015)$ & $(0.065)$ & $(0.026)$ \\
\hline
\end{tabular}

Note: Based on author's calculations using TRS and TSR data on employees of IPS schools from 1971 to 1992 . Only employees ages 50 and older and those vested in the pension system are included in the analysis. Estimates presented are from a differences-in-differences specification in which eligibility for pensions and retiree health insurance are interacted with age-group fixed effects as indicated by the row headers. The specification includes controls for employee

characteristics and district fixed effects as well as age-by-year and experience-by-year fixed effects. ***, ** and * represent statistical significance at the 1,5 and 10 percent levels, respectively. 